\title{
EMX2 Gene
}

National Cancer Institute

\section{Source}

National Cancer Institute. EMX2 Gene. NCI Thesaurus. Code C132084.

This gene is involved in development and transcriptional regulation. 